\title{
Pulverized Mangifera indica (Mango) Seed-kernel Modulated Serum Lipid Profile in Monosodium Glutamate-challenged Rats
}

\author{
Anthony Cemaluk C. Egbuonu (Corresponding author) \\ Dept. of Biochemistry, Michael Okpara University of Agriculture Umudike, Nigeria \\ Tel: 234-80-3636-6565Ｅ-mail: tonycemalukegbuonu@yahoo.com; \\ egbuonu.anthony@mouau.edu.ng \\ Gladys A. Ekwuribe \\ Dept. of Biochemistry, Michael Okpara University of Agriculture Umudike, Nigeria
}

Received: July 6, 2017 Accepted: August 4, 2017 Published: August 6, 2017

Doi: 10.5296/jab.v5i2.11649 URL: http://doi.org/10.5296/jab.v5i2.11649

\begin{abstract}
Mangifera indica seed kernel was assessed for antinutirent content and effects on serum lipid profile of monosodium glutamate-challenged rats. Group A rats received $8000 \mathrm{mg} / \mathrm{kg}$ body weight, b.w of monosodium glutamate (MSG). Group B rats received the sample extract (300 $\mathrm{mg} / \mathrm{kg}$ b.w). Group C rats were sham-administered distilled water. Groups D and E rats received $8000 \mathrm{mg} / \mathrm{kg}$ b.w of MSG in addition to 200 and $400 \mathrm{mg} / \mathrm{kg} \mathrm{b.w}$, respectively of sample extract. Tannin $(29.21 \pm 5.39 \mathrm{mg} / 100 \mathrm{~g})$ was highest $(\mathrm{p}<0.05)$ while phytate $(0.38 \pm 0.02$ $\mathrm{mg} / 100 \mathrm{~g}$ ) was least. After fourteen days daily oral exposure, MSG-exposed rats had higher $(\mathrm{p}<0.05)$ total cholesterol $(\mathrm{CHOL})$, triacylglycerol $(\mathrm{TAG})$ and low density lipoprotein (LDL) but lower $(p<0.05)$ high density lipoprotein (HDL) concentration compared to rats in the other groups. MSG-intoxicated rats co-treated respectively with 200 and $400 \mathrm{mg} / \mathrm{kg}$ b.w of the extract had dose dependent reduction $(p<0.05)$ compared to the corresponding effects in non-extract-co-treated MSG-intoxicated rats. Compared to others, rats in the Extract group had higher $(\mathrm{p}<0.05)$ CHOL: TAG but lower $(\mathrm{p}<0.05)$ TAG:CHOL ratios while rats in the MSG-group had higher $(p<0.05)$ HDL:LDL but lower $(p<0.05)$ LDL:HDL ratios. Results demonstrated the preponderance of tannin in, and significant serum lipid lowering potential in normal and MSG-challenged rats of, the sample. Studies using
\end{abstract}


antinutrient-process-reduced sample in hyperlipidemia-related health-challenged models and collaborating the suggested implication of lipid-profile-component-ratios are warranted and recommended.

Keywords: Tannins, Phytates, Trypsin inhibitor, Cholesterol-triacylglycerol ratio, High density lipoprotein-low density lipoprotein ratio

\section{Introduction}

Monosodium glutamate (MSG), a flavor enhancing food additive (Husarova \& Ostatnikova, 2013; Veni et al., 2010) which could be abused owing to its non-indication on the labels of most packaged foods (Egbuonu, 2012; Egbuonu et al., 2009a) was reportedly toxic in animals (Manal \& Nawal, 2012; Egbuonu et al., 2010b,c,d; Mariyamma et al., 2009). Thus, its safety has generated much controversy. Monosodium glutamate, as the name suggests, has a proton or hydrogen moiety at the carboxylic part of glutamic acid substituted by a sodium ion. And, in physiological condition MSG is expected to dissociate into free glutamate and sodium ion. This implies that the reported adverse effects of MSG could be exerted by MSG or any of its dissociation products. For instance, glutamate, an amino acid but an exitotoxin, is implicated in both physiological and pathological processes (Mattson 2008) mediated via glutamate receptors (Collison et al., 2012).

Lipid profile including total cholesterol, LDL-cholesterol, HDL-cholesterol and triacylglycerol are important diagnostic tools, and effects of MSG ingestion on lipid profile have been reported. Recently, Okediran et al. (2014) reported a significant increase in the plasma total cholesterol and LDL-cholesterol but a non-significant decrease in TAG and HDL-cholesterol in MSG-treated rats compared to control. This was supported by earlier report suggesting attendant dysfunctions related to impaired lipid metabolism including diabetes and cardiovascular diseases (Egbuonu et al., 2010d; Schummer et al., 2008). The increasing need for herbs and foods apparently heightened by the additional health-burden caused by food additives, notably monosodium glutamate (Egbuonu \& Osakwe, 2011; Egbuonu et al., 2010a,b,c; Egbuonu et al., 2009a) necessitate increasing search for plants and plant parts with nutraceutical potentials (Egbuonu, 2015a; Egbuonu \& Nwankwo, 2012).

Mango, a common and an economically important tropical fruit-bearing plant belongs to the genus Mangifera (Zahedi et al., 2016) and family Anacardiaceae (Shah et al., 2010). Mango plant parts have health benefits associated with varied phyto-nutrients including mangiferin (Shah et al., 2010; Li et al., 2010; Ajila \& Prasada-Rao, 2008). Reports of pharmacological activities of $M$. indica plant parts abound and include hypolipidemic (Jagetia et al., 2005), anti-microbial (Shabani \& Sayadi, 2014; Vega-Vega et al., 2013), anti-diabetic (Bhowmik et al., 2009), anti-proliferative (Timsina et al., 2015; Ali et al., 2012; Noratto et al., 2010) and nephroprotective (Amien et al., 2015) activities. Therefore, M. indica (mango) fruit is extensively exploited for food and drugs resulting to the generation of mango seed as waste (Yatnatti et al., 2014). In a recent study, M. indica seed kernel usually discarded along with the mango seed mitigated monosodium glutamate-intoxicated rats' kidney histology and bio-functions (Egbuonu \& Oriji, 2017).

The pharmacologic utilization of $M$. indica seed kernel, as other plant-sourced foods, could be limited by diverse natural compounds (Shanthakumari et al., 2008) including antinutrients . 
For instance, tannins and phytates are known to limit the nutrient value of plant foods by chelating (binding and precipitating) many organic compounds including amino acids, proteins, irons and alkaloids (Gemede \& Ratta, 2014; Soetan \& Oyewole, 2009). Thus, this study aimed at determining some antinutrients in the mango seed kernel and the effects of the mango seed kernel extract on the serum lipid profile of normal and monosodium glutamate-challenged rats. The objectives of the study set to achieve the aim as stated were to determine the tannins, phytate and trypsin inhibitor contents of Mangifera indica seed kernel and to evaluate the effects of the extract of Mangifera indica seed kernel on the serum lipid profile (CHOL, TAG, LDL and HDL concentration as well as CHOL: TAG, TAG: CHOL, HDL: LDL and LDL: HDL ratios) of normal and monosodium glutamate-challenged rats.

\section{Materials and Methods}

\subsection{Sample Procurement and Identification}

A commercially available brand of MSG (99\% purity) was procured from Ubani market, a daily food condiments market in Umuahia, south east Nigeria. Ethanol, sodium carbonate, tannic acid, hydrochloric acid, ammonium thiocyanate, iron chloride, 4-aminoantipyrine, sodium cholate p-hydroxybenzenesulfonate and other chemicals used were certified analytical grade and products of reputable companies. They were purchased from reputable chemical dealers and were used without further purification.

This study was conducted between June and August, 2016. Fresh mango fruits collected from a particular mango tree were purchased in June, 2016 at Orie ugba, a fruit and foodstuff market in Umuahia, Abia state. The mango fruits were identified and authenticated as Mangifera indica (German variety) by a taxonomist in the department of Plant Science and Biotechnology, Michael Okpara University of Agriculture Umudike, Nigeria.

\subsection{Sample Preparation and Extraction}

The mango fruits (German variety) were thoroughly washed using tap water. The fleshy part of each fruit was removed to obtain the seed stones which were sun-dried for three days. The sun-dried seed stones were carefully cut with clean table knife to remove the stony seed coat and obtain the seed kernels. The kernels thus obtained were chopped with home choice knife into bits and sun-dried for one week (seven days). The dried mango seed-kernels were pulverized using Arthur Thomas Laboratory Mill, Crypto Model, USA. The pulverized mango seed-kernel was extracted with ethanol (98\%) as described earlier (Egbuonu, 2015b) and stored in a refrigerator at $4{ }^{\circ} \mathrm{C}$ until used.

\subsection{Animal Study}

\subsubsection{Animal Procurement and Exposure Groups}

Twenty adult male albino rats (weight range, 104-170 g) used in this study were procured from the animal house of the Faculty of Biological Sciences, University of Nigeria, Nsukka. The animals were acclimatized for 2 weeks and then randomized (based on weight) to five experimentation groups comprising four rats each.

Rats in the control group were sham-dosed distilled water (without either the extract or MSG) while rats in the MSG group were fed intoxicating dose $(8000 \mathrm{mg} / \mathrm{kg}$ body weight) of MSG according to Mariyamma et al. (2009). Rats in the extract group were fed mango seed kernel 
extract $(300 \mathrm{mg} / \mathrm{kg}$ body weight while rats) in the MSG + low extract group were concomitantly fed the mango seed kernel extract (200 mg/kg body weight) and intoxicating dose of MSG ( $8000 \mathrm{mg} / \mathrm{kg}$ body weight) whereas rats in the MSG + high extract group were co-administered $400 \mathrm{mg} / \mathrm{kg}$ body weight of the mango seed kernel extract and intoxicating dose of MSG ( $8000 \mathrm{mg} / \mathrm{kg}$ body weight). The exposure was per oral and daily for 14 days.

\subsubsection{Sacrifice, Blood Sample Collection and Preparation}

After 2 weeks (14 days) exposure, the rats were sacrificed the next day after overnight fast by cardiac puncture technique (Lucas et al., 2004) and the blood sample of the respective rats was collected individually into clean polystyrene tubes, allowed to clot and respectively centrifuged at $3000 \mathrm{rpm}$ for 10 minutes. The resultant serum was respectively collected into polystyrene tubes and stored in deep freezer for the determination of serum total cholesterol (CHOL), triacylglycerol (TAG), high density lipoprotein-cholesterol (HDL) and low densisty lipoprotein-cholesterol (LDL) concentrations. Important diagnostic ratios including CHOL:T AG, TAG:CHOL, LDL:HDL and HDL:LDL ratios were calculated from the corresponding value as obtained in this study.

\subsubsection{Ethical Consideration}

This study which is a continuation of our line of studies on the evaluation of biochemical effects of mango seed-kernel extract on normal and monosodium glutamate-challenged experimental models considered and adhered to the standard ethical use of experimental animals. Throughout out the experimentation (acclimatization and exposure periods), all rats were housed at $25{ }^{\circ} \mathrm{C}$ in stainless steel cages under normal daylight/dark cycle and humid tropical conditions. The rats were allowed free access to rat's feed (Vital feed, Jos Nigeria) and tap water, and generally received humane care in accordance with the guidelines of the National institute of Health, USA for ethical treatment of laboratory animals as approved by the various (departmental and college) ethical committees of Michael Okpara University of Agriculture Umudike, Nigeria.

\subsection{Determination of Tannin, Phytate and Trypsin Inhibitor Contents}

The concentration of tannin in the mango seed-kernel was determined by the method of Jaffe et al. (2000). One gram of the sample was dissolved in $10 \mathrm{ml}$ distilled water, agitated and left to stand for 30 minutes at room temperature. Each sample was centrifuged and the extract recovered. Then, $2.5 \mathrm{ml}$ of the supernatant was dispersed into $50 \mathrm{ml}$ volumetric flask. Similarly, $2.5 \mathrm{ml}$ of standard tannic acid solution was dispersed into a separate $50 \mathrm{ml}$ flask. A $10 \mathrm{ml}$ Folin-Dennis reagent was measured in each flask followed by $2.5 \mathrm{ml}$ of saturated sodium carbonate $\left(\mathrm{Na}_{2} \mathrm{CO}_{3}\right)$ solution. The mixture was diluted to $50 \mathrm{ml}$ in the flask and incubated for $90 \mathrm{~min}$ at room temperature. The absorbance of each sample and standard was measured at $250 \mathrm{~nm}$ with the reagent blank set at zero. The corresponding concentration of $\operatorname{tannin}(\mathrm{mg} / 100 \mathrm{~g})$ in the sample was calculated in relation with that of the standard.

The phytate content in the mango seed-kernel was determined as phytic acid using the procedure described by Lucas and Markaka (1975). This entailed weighing $2 \mathrm{~g}$ of the sample into $250 \mathrm{ml}$ conical flask. The mango seed kernel sample was soaked in $100 \mathrm{ml}$ of $2 \%$ concentrated hydrochloric acid (HCL) in a conical flask for 3 hours and then filtered through a double layered filter paper. Then, $50 \mathrm{ml}$ of the filtrate was placed in a $250 \mathrm{ml}$ beaker and 
$107 \mathrm{ml}$ of distilled water added to give proper acidity. This was followed by the addition of $10 \mathrm{ml}$ of $0.3 \%$ ammonium thiocyanate solution to each sample solution as indicator before titrating with standard iron chloride solution $(0.00195 \mathrm{~g}$ iron $/ \mathrm{ml})$ to the end point shown by brownish-yellow coloration that persisted for 5 minutes. The corresponding phytic acid concentration $(\mathrm{mg} / 100 \mathrm{~g})$ in the sample was calculated in relation with that of the standard.

The concentration of trypsin inhibitor in the sample was determined according to the method of Prokopet and Unlenbruck (2002). One gram of the sample was dispersed in $50 \mathrm{ml}$ of $0.5 \mathrm{M}$ sodium chloride $(\mathrm{NaCl})$ solution. The mixture was stirred for 30 minutes at room temperature and centrifuged at $1500 \mathrm{rpm}$ for 5 minutes. The supernatants were filtered and the filtrate used for the assay. This assay involved the addition of $2 \mathrm{ml}$ of the standard trypsin solution to $10 \mathrm{ml}$ of the filtrate as the substrate of the sample. The absorbance of the mixture was taken at $410 \mathrm{~nm}$ using $10 \mathrm{ml}$ of the same substrate as blank. The corresponding trypsin inhibitor concentration $(\mu 1 / \mathrm{mg})$ in the sample was calculated in relation with that of the standard.

\subsection{Determination of Serum CHOL Concentration}

Serum CHOL concentration was determined by the slightly modified colorimetric method of Zlatkis et al. (1953). Five $\mathrm{ml}$ of ethanol was added to $0.1 \mathrm{ml}$ of serum. The content was shaken and centrifuged at $3000 \mathrm{x}$ g for $5 \mathrm{~min}$ and the resultant supernatant was aspirated into another tube. Then, $2 \mathrm{ml}$ of chromogen was added to the tube and the sample was allowed to stand for $40 \mathrm{~min}$. after which the absorbance was measured at $550 \mathrm{~nm}$.

\subsection{Determination of Serum Triacylglycerol (TAG) Concentration}

Serum TAG concentration was determined by the method of Calson (1963). This was based on the principle that glycerol obtained after alkaline hydrolysis of the glycerides could be measured colorimetricaly at $570 \mathrm{~nm}$. To $0.1 \mathrm{ml}$ of the sample pipetted into a labelled clean tube, $1.0 \mathrm{ml}$ of trichloroacetic acid (TCA) was added, mixed and then centrifuged at $250 \mathrm{rpm}$ for 10 minutes. The content was allowed to stand for 20 minutes at room temperature and the absorbance of the sample and standard read against the blank at $570 \mathrm{~nm}$.

\subsection{Determination of Serum High Density Lipoprotein-Cholesterol Concentration}

Serum HDL-cholesterol concentration was determined using the method of Albers et al. (1978) as contained in QCA commercial kits. The was based on the principle that low density lipoprotein (LDL) and very low density lipoproteins (VLDL) cholesterols are precipitated from serum by the action of polysaccharide in the presence of divalent cations to allow for spectrophotometric determination or measurement of high density lipoprotein-cholesterol (HDL) present in the supernatant.

\subsection{Calculation of Some Lipid Profile Component Ratios}

Some lipid profile component ratios, including cholesterol-triacylglycerol (CHOL:TAG), triacylglycerol-cholesterol (TAG:CHOL), low density lipoprotein-high density lipoprotein (LDL: HDL) and high density lipoprotein-low density lipoprotein (HDL:LDL) ratios were calculated from the corresponding results of this study as in earlier studies (Egbuonu \& Osakwe, 2011; Egbuonu \& Ezeanyika, 2012).

\subsection{Statistical Analysis}

Antinutrient data from triplicate determinations and the lipid profile data from sample size, $n$, of four rats were evaluated using one-way analysis of variance (ANOVA) as described 
(Egbuonu et al., 2009b).Results were given as mean \pm standard error of mean (SEM). The difference in mean was considered significance at $\mathrm{p}<0.05$.

\section{Results}

\subsection{Antinutrient Content}

The results of the antinutrients content of mango seed were as shown on Table 1 above. Tannin content $(29.21 \pm 5.39 \mathrm{mg} / 100 \mathrm{~g})$ was higher than the other determined antinutrients while the least was phytate $(0.38 \pm 0.02) \mathrm{mg} / 100 \mathrm{~g}$.

Table 1. Some antinutrient contents in the pulverized $M$. indica seed kernel

\begin{tabular}{llll}
\hline & Tannin $(\mathrm{mg} / 100 \mathrm{~g})$ & Trypsin inhibitor $(\mu \mathrm{l} / \mathrm{mg})$ & Phytate $(\mathrm{mg} / 100 \mathrm{~g})$ \\
\hline Concentration & $29.21 \pm 5.39$ & $9.53 \pm 0.02$ & $0.38 \pm 0.02$ \\
\hline
\end{tabular}

Value presented as mean \pm SEM of triplicate determinations. Significant difference at $\mathrm{p}<0.05$

\subsection{Lipid Profile}

The result as shown on Table 2 revealed that after fourteen day daily oral exposure, rats in the MSG group had higher $(p<0.05)$ serum total cholesterol concentration compared to rats in the other groups. However, MSG-intoxicated rats co-treated respectively with $200 \mathrm{mg} / \mathrm{kg}$ and $400 \mathrm{mg} / \mathrm{kg}$ body weight of the sample extract showed a significant $(\mathrm{p}<0.05)$ dose dependent reduction in the serum total cholesterol concentration compared to the corresponding effect observed in rats exposed to MSG alone. The observation relative to the control was highest $(10.59 \%)$ in the rats exposed to MSG alone and least $(0.59 \%)$ in the rats exposed to MSG together with highest concentration of the extract. The observed change relative to the MSG group was highest in rats in the control (9.57\%) followed by rats in the MSG + highest extract group $(9.04 \%)$.

As depicted on Table 3, rats in the MSG Group had higher $(\mathrm{p}<0.05)$ serum triacylglycerol concentration compared to rats in the other groups. However, MSG-intoxicated rats co-treated respectively with $200 \mathrm{mg} / \mathrm{kg}$ and $400 \mathrm{mg} / \mathrm{kg}$ body weight of the sample extract showed a significant $(\mathrm{p}<0.05)$ dose dependent reduction in the serum triacylglycerol concentration compared to the corresponding effect observed in rats exposed to MSG alone. The observation relative to the control was highest $(16.03 \%)$ in the rats exposed to the extract alone followed by $(15.38 \%)$ in the rats exposed to MSG together with highest concentration of the extract. Similarly, the observed reduction relative to the MSG group was highest in rats in the extract group (10.27\%) followed by that in the MSG + highest extract group (9.59\%).

Rats in the MSG Group had lower $(\mathrm{p}<0.05)$ high density lipoprotein concentration compared to rats in the other groups. However, MSG-intoxicated rats co-treated respectively with 200 $\mathrm{mg} / \mathrm{kg}$ and $400 \mathrm{mg} / \mathrm{kg}$ body weight of the sample extract showed a lower $(\mathrm{p}<0.05)$ high density lipoprotein concentration compared to that of rats in the control and in the extract groups. The observation relative to the control was equal $(20.73 \%)$ but opposite in the MSG and Extract groups while the observed change relative to the MSG group was highest 
$(52.31 \%)$ in rats in the Extract group and least (20.77\%) in the MSG + highest extract group of rats (Table 4).

As shown on Table 5, after fourteen day daily oral exposure, rats in the MSG Group had higher $(\mathrm{p}<0.05)$ low density lipoprotein cholesterol concentration compared to rats in the other groups. However, MSG-intoxicated rats co-treated respectively with $200 \mathrm{mg} / \mathrm{kg}$ and $400 \mathrm{mg} / \mathrm{kg}$ body weight of the sample extract showed a significant $(\mathrm{p}<0.05)$ dose dependent reduction in low density lipoprotein cholesterol concentration compared to that in rats exposed to MSG alone. The observation relative to the control was highest (155.25\%) in the rats exposed to MSG alone and least $(45.88 \%)$ in the rats exposed to the extract alone. The observed reduction relative to the MSG group was highest in rats in the control $(60.83 \%)$ followed by those in the extract group (42.86\%) but least in the MSG + least extract group $(25.81 \%)$.

Table 2. Effect of $M$. indica (mango) seed kernel extract on the serum CHOL concentration $\left(\mathrm{mg} 100 \mathrm{ml}^{-1}\right)$ of normal and monosodium glutamate-intoxicated rats

\begin{tabular}{|c|c|c|c|}
\hline Groups & $\begin{array}{l}\mathrm{CHOL} \\
\left.100 \mathrm{ml}^{-1}\right)\end{array} \quad(\mathrm{mg}$ & $\begin{array}{l}\text { Change relative to } \\
\text { the Control }(\%)\end{array}$ & $\begin{array}{l}\text { Change relative to } \\
\text { MSG group (\%) }\end{array}$ \\
\hline $\begin{array}{l}\text { Control } \\
\text { (distilled water } 2 \mathrm{ml} / \mathrm{kg} \mathrm{b.w)}\end{array}$ & $3.40 \pm 0.07 *$ & 0.00 & -9.57 \\
\hline MSG (8000 mg/kg b.w) & $3.76 \pm 0.09$ & +10.59 & 0.00 \\
\hline Extract $(300 \mathrm{mg} / \mathrm{kg}$ b.w) & $3.48 \pm 0.10$ & +2.35 & -7.18 \\
\hline $\begin{array}{l}\text { MSG }(8000 \mathrm{mg} / \mathrm{kg} \text { b.w })+ \\
\text { Extract } 200 \mathrm{mg} / \mathrm{kg} \mathrm{b.w})\end{array}$ & $3.47 \pm 0.11^{*}$ & +2.06 & -7.71 \\
\hline $\begin{array}{l}\text { MSG }(8000 \mathrm{mg} / \mathrm{kg} \mathrm{b.w})+ \\
\text { Extract }(400 \mathrm{mg} / \mathrm{kg} \mathrm{b.w})\end{array}$ & $3.42 \pm 0.10^{*}$ & +0.59 & -9.04 \\
\hline
\end{tabular}

Value presented as mean \pm SEM of sample size, $n=4$ rats. + denotes higher by; - denotes lower by. Significant difference at $\mathrm{p}<0.05$. * significantly different from MSG $(\mathrm{P}<0.05)$ (one way ANOVA followed by post-hoc LSD).

Table 3. Effect of $M$. indica (mango) seed kernel extract on the serum TAG concentration (mg $100 \mathrm{ml}^{-1}$ ) of normal and monosodium glutamate-intoxicated rats

\begin{tabular}{llll}
\hline Groups & $\begin{array}{l}\text { TAG } \\
\left.100 \mathrm{ml}^{-1}\right)\end{array}$ & $\begin{array}{l}(\mathrm{mg} \\
\text { Change relative to } \\
\text { the control (\%) }\end{array}$ & $\begin{array}{l}\text { Change relative to } \\
\text { MSG group (\%) }\end{array}$ \\
\hline Control & & & +6.84 \\
(distilled water $2 \mathrm{ml} / \mathrm{kg} \mathrm{b.w})$ & $1.56 \pm 0.04^{*}$ & 0.00 & 0.00 \\
MSG (8000 mg/kg b.w) & $1.46 \pm 0.03$ & -6.41 & -10.27 \\
Extract $(300 \mathrm{mg} / \mathrm{kg} \mathrm{b.w})$ & $1.31 \pm 0.01 *$ & -16.03 & \\
\hline
\end{tabular}


MSG (8000 mg/kg b.w +

Extract $200 \mathrm{mg} / \mathrm{kg}$ b.w)

$1.41 \pm 0.02 \quad-9.62$

MSG (8000 mg/kg b.w

b.w) $+1.32 \pm 0.01 * \quad-15.38$

$-9.59$

Extract (400 mg/kg b.w)

Value presented as mean \pm SEM of sample size, $n=4$ rats. + denotes higher by; - denotes lower by. Significant difference at $\mathrm{p}<0.05$. *significantly different from MSG $(\mathrm{P}<0.05)$ (one way ANOVA followed by post-hoc LSD).

Table 4. Effect of $M$. indica (mango) seed kernel extract on the serum HDL-CHOL concentration $\left(\mathrm{mg} 100 \mathrm{ml}^{-1}\right)$ of normal and monosodium glutamate-intoxicated rats

\begin{tabular}{|c|c|c|c|}
\hline Groups & $\begin{array}{l}\text { HDL-CHOL (mg } \\
\left.100 \mathrm{ml}^{-1}\right)\end{array}$ & $\begin{array}{l}\text { Change relative to } \\
\text { the control }(\%)\end{array}$ & $\begin{array}{l}\text { Change relative to } \\
\text { MSG group (\%) }\end{array}$ \\
\hline $\begin{array}{l}\text { Control } \\
\text { (distilled water } 2 \mathrm{ml} / \mathrm{kg} \\
\text { b.w) }\end{array}$ & $1.64 \pm 0.07 *$ & 0.00 & +26.15 \\
\hline MSG (8000 mg/kg b.w) & $1.30 \pm 0.03$ & -20.73 & 0.00 \\
\hline Extract (300 mg/kg b.w) & $1.98 \pm 0.05^{*}$ & +20.73 & +52.31 \\
\hline $\begin{array}{l}\text { MSG }(8000 \mathrm{mg} / \mathrm{kg} \mathrm{b.w}+ \\
\text { Extract } 200 \mathrm{mg} / \mathrm{kg} \mathrm{b.w})\end{array}$ & $1.58 \pm 0.07 *$ & -3.66 & +21.54 \\
\hline $\begin{array}{l}\text { MSG }(8000 \mathrm{mg} / \mathrm{kg} \text { b.w }+ \\
\text { Extract }(400 \mathrm{mg} / \mathrm{kg} \mathrm{b.w})\end{array}$ & $1.57 \pm 0.06^{*}$ & -4.27 & +20.77 \\
\hline
\end{tabular}

Value presented as mean \pm SEM of sample size, $n=4$ rats. + denotes higher by; - denotes lower by. Significant difference at $\mathrm{p}<0.05$. * significantly different from MSG $(\mathrm{P}<0.05)$ (one way ANOVA followed by post-hoc LSD).

Table 5. Effect of $M$. indica (mango) seed kernel extract on the serum LDL-CHOL concentration $\left(\mathrm{mg} 100 \mathrm{ml}^{-1}\right)$ of normal and monosodium glutamate-intoxicated rats

\begin{tabular}{|c|c|c|c|}
\hline Groups & $\begin{array}{l}\text { LDL-CHOL (mg } \\
\left.100 \mathrm{ml}^{-1}\right)\end{array}$ & $\begin{array}{l}\text { Change relative to } \\
\text { the control }(\%)\end{array}$ & $\begin{array}{l}\text { Change relative to } \\
\text { MSG group (\%) }\end{array}$ \\
\hline $\begin{array}{l}\text { Control } \\
\text { (distilled water } 2 \quad \mathrm{ml} / \mathrm{kg} \\
\text { b.w) }\end{array}$ & $0.85 \pm 0.05^{*}$ & 0.00 & -60.83 \\
\hline MSG (8000 mg/kg b.w) & $2.17 \pm 0.11 *$ & +155.29 & 0.00 \\
\hline Extract $(300 \mathrm{mg} / \mathrm{kg}$ b.w) & $1.24 \pm 0.13^{*}$ & +45.88 & -42.86 \\
\hline $\begin{array}{l}\text { MSG }(8000 \mathrm{mg} / \mathrm{kg} \mathrm{b.w} \mathrm{+} \\
\text { Extract } 200 \mathrm{mg} / \mathrm{kg} \mathrm{b.w})\end{array}$ & $1.61 \pm 0.13^{*}$ & +89.41 & -25.81 \\
\hline
\end{tabular}


MSG (8000 mg/kg b.w +

Extract $(400 \mathrm{mg} / \mathrm{kg}$ b.w)

$1.58 \pm 0.10^{*}$

$+85.88$

$-27.19$

Value presented as mean \pm SEM of sample size, $n=4$ rats. + denotes higher by; - denotes lower by. Significant difference at $\mathrm{p}<0.05$. * significantly different from $\mathrm{MSG}(\mathrm{P}<0.05)$ (one way ANOVA followed by post-hoc LSD).

\subsection{Some Lipid Profile Ratios}

As depicted on Table 6, after fourteen day daily oral exposure, rats in the Extract group had higher $(\mathrm{p}<0.05)$ CHOL:TAG ratio but lower $(\mathrm{p}<0.05)$ TAG:CHOL ratio compared to rats in the other groups. Similarly, the observation relative to the control was highest $(22.02 \%$ and $19.57 \%$, respectively for CHOL:TAG and TAG:CHOL ratios) in the rats exposed to Extract alone. The observed increase in CHOL:TAG ratio relative to the MSG group was highest $(3.10 \%)$ in rats in the Extract group while the observed decrease in TAG:CHOL ratio relative to the MSG group was highest (5.13\%) also in rats in the Extract group.

As depicted on Table 7, after fourteen day daily oral exposure, rats in the MSG group had lower $(\mathrm{p}<0.05)$ HDL:LDL ratio but higher $(\mathrm{p}<0.05)$ LDL:HDL ratio compared to rats in the other groups. Similarly, the observations relative to the control was highest $(225.69 .27 \%$ and $225.49 \%$, respectively for HDL: LDL and LDL:HDL ratios) in the rats exposed to MSG alone. However, the observed increase in HDL:LDL ratio relative to the MSG group was highest $(225.42 \%)$ in rats in the Control group while the observed decrease in LDL:HDL ratio relative to the MSG group was highest (69.27\%) also in rats in the Control group.

Table 6. Effect of $M$. indica (mango) seed kernel extract on the serum CHOL: TAG ratio of normal and monosodium glutamate-intoxicated rats

\begin{tabular}{|c|c|c|c|}
\hline Groups & $\begin{array}{l}\text { CHOL:TAG } \\
\text { ratio } \\
\text { (TAG:CHOL } \\
\text { ratio) }\end{array}$ & $\begin{array}{l}\text { Change relative to the } \\
\text { control }(\%)\end{array}$ & $\begin{array}{l}\text { Change relative to } \\
\text { MSG group }(\%)\end{array}$ \\
\hline $\begin{array}{l}\text { Control } \\
\text { (distilled water } 2 \mathrm{ml} / \mathrm{kg} \\
\text { b.w) }\end{array}$ & $2.18(0.46)$ & 0.00 & $-15.50(+17.95)$ \\
\hline MSG (8000 mg/kg b.w) & $2.58(0.39)$ & $+18.35(-15.22)$ & $0.00(0.00)$ \\
\hline Extract $(300 \mathrm{mg} / \mathrm{kg}$ b.w) & $2.66(0.37)$ & $+22.02(-19.57)$ & $+3.10(-5.13)$ \\
\hline $\begin{array}{l}\text { MSG }(8000 \mathrm{mg} / \mathrm{kg} \text { b.w }+ \\
\text { Extract } 200 \mathrm{mg} / \mathrm{kg} \mathrm{b.w})\end{array}$ & $2.46(0.41)$ & $+12.84(-10.87)$ & $-4.65(+5.13)$ \\
\hline $\begin{array}{l}\text { MSG }(8000 \mathrm{mg} / \mathrm{kg} \text { b.w }+ \\
\text { Extract }(400 \mathrm{mg} / \mathrm{kg} \text { b.w })\end{array}$ & $2.59(0.38)$ & $+18.81(-17.39)$ & $+0.39(-2.56)$ \\
\hline
\end{tabular}

Value presented as mean \pm SEM of sample size, $\mathrm{n}=4$ rats. + denotes higher by; - denotes lower by. Significant difference at $\mathrm{p}<0.05$. *significantly different from $\mathrm{MSG}(\mathrm{P}<0.05)$ (one 
way ANOVA followed by post-hoc LSD).

Table 7. Effect of $M$. indica (mango) seed kernel extract on the serum HDL: LDL ratio of normal and monosodium glutamate-intoxicated rats

\begin{tabular}{|c|c|c|c|}
\hline Groups & $\begin{array}{l}\text { HDL:LDL } \\
\text { ratio } \\
\text { (LDL:HDL } \\
\text { ratio) }\end{array}$ & $\begin{array}{l}\text { Change relative to the } \\
\text { control }(\%)\end{array}$ & $\begin{array}{l}\text { Change relative to } \\
\text { MSG group (\%) }\end{array}$ \\
\hline $\begin{array}{l}\text { Control } \\
\text { (distilled water } 2 \mathrm{ml} / \mathrm{kg} \\
\text { b.w) }\end{array}$ & $1.92(0.51)$ & 0.00 & $+225.42(-69.27)$ \\
\hline MSG (8000 mg/kg b.w) & $0.59(1.66)$ & $-69.27(+225.49)$ & $0.00(0.00)$ \\
\hline Extract (300 mg/kg b.w) & $1.59(0.62)$ & $-17.19(+21.57)$ & $+169.49(-62.65)$ \\
\hline $\begin{array}{l}\text { MSG }(8000 \mathrm{mg} / \mathrm{kg} \mathrm{b.w}+ \\
\text { Extract } 200 \mathrm{mg} / \mathrm{kg} \mathrm{b.w})\end{array}$ & $0.98(1.01)$ & $-48.96(+98.03)$ & $+66.10(-39.16)$ \\
\hline $\begin{array}{l}\text { MSG }(8000 \mathrm{mg} / \mathrm{kg} \mathrm{b.w}+ \\
\text { Extract }(400 \mathrm{mg} / \mathrm{kg} \mathrm{b.w})\end{array}$ & $0.99(1.00)$ & $-48.44(+96.08)$ & $+67.80(-39.76)$ \\
\hline
\end{tabular}

Value presented as mean \pm SEM of sample size, $\mathrm{n}=4$ rats. + denotes higher by; - denotes lower by. Significant difference at $\mathrm{p}<0.05$. *significantly different from $\mathrm{MSG}(\mathrm{P}<0.05)$ (one way ANOVA followed by post-hoc LSD).

\section{Discussion}

This study determined some antinutrients in Mangifera indica (mango) seed-kernel and the effects of ethanol extract of the seed-kernel on serum lipid profile of normal and monosodium glutamate-challenged male albino rats (weight range, 104-107 g; 5 groups; $n=4$ ). The result revealed the preponderance of the determined antinutrients in the Mangifera indica seed kernel although tannin content $(29.21 \pm 5.39 \mathrm{mg} / 100 \mathrm{~g})$ was highest while phytate content $(0.38 \pm 0.02) \mathrm{mg} / 100 \mathrm{~g})$ was the least. The content of these antinutrients in M. indica (german variety) seed kernel, notably tannin could not compare with that report by Fowomola (2010) also in $M$. indica seed kernel. However, Fowomola (2010) did neither indicate the $M$. indica variety nor clarify whether the whole seed or the seed kernel was used. Phytochemical and nutrient contents of mango vary across mango cultivars (Rocha-Ribeiro, et al., 2007) and varieties (Abdalla et al., 2007), implying possible variation in their effects in, when used by, animals. Nevertheless, the comparatively high content of notably tannin reported in this study suggests that the German variety of mango seed kernel may be toxic when consumed. Antinutrients and proximate content of plant-sourced foods are easily removed by simple processing methods including boiling and roasting (Nzewi \& Egbuonu, 2011a; Nzewi \& Egbuonu, 2011b). Thus these and other methods for reducing antinutrients should be applied hence recommended to reduce or eliminate totally the antinutrients contained in the seed 
kernel so as to enable proper application of the seed kernel in both animal feeds and in industries.

To the knowledge of the authors, this is the first study that investigated the effect of mango seed kernel on lipid profile of MSG-intoxicated animal model. After fourteen days daily oral exposure, rats in the MSG Group had higher $(\mathrm{p}<0.05)$ total cholesterol, triacylglycerol and low density lipoprotein but lower $(p<0.05)$ high density lipoprotein concentration compared to rats in the other groups. Notably, the rats intoxicated with MSG also showed a significantly higher serum level of CHOL and TAG. This confirmed the reported hyperlipidemia in rats exposed to $8 \mathrm{~g} / \mathrm{kg}$ bw of MSG (Mariyamma et al., 2009) and concurred with other findings (Okediran et al., 2014), indicating altered cholesterol and triacylglycerol metabolism and the attendant risk of cardiovascular diseases in the rats (Egbuonu et al., 2010d). Generally, elevated serum CHOL and TAG concentrations indicate hyperlipidemia. However, treating rats with $M$. indica seed kernel extract led to significant elevation of their serum HDL-cholesterol concentration. Also, MSG-intoxicated rats co-treated respectively with 200 and $400 \mathrm{mg} / \mathrm{kg}$ b.w of the sample extract showed a significant $(\mathrm{p}<0.05)$ dose dependent reduction compared to the corresponding effects observed in rats exposed to MSG alone. This suggested modulation of MSG-induced effects on the rats lipid profile irrespective of co-treated sample dose, and possible promising protective role of $M$. indica seed kernel against the adverse effects related to MSG-induced responses in the rats' serum lipid profile. The health implication of this modulation is noteworthy. The association between a low level of HDL-cholesterol and an increased risk of CVD was established (Assmann \& Gotto, 2004). Low level of HDL-cholesterol plays a direct role in the atherogenic process and therapeutic intervention to raise HDL-cholesterol is widely encouraged. This study showed that $M$. indica seed kernel extract exerted a significant dose dependent decrease in TAG, CHOL and LDL and a significant dose dependent increase in HDL, hence did significantly counter the attendant hyperlipidemic-related adverse effects elicited by MSG intoxication. Further studies are warranted to determine the exact component in $M$. indica responsible.

The corresponding ratios of the components of lipid profile are not frequently considered though they could be diagnostic. Millan et al. (2009) reported that lipid profile component ratios have greater risk factors predictive value than the use of isolated parameters. In this study, some ratios were computed. Compared to other groups, rats in the Extract group had higher $(\mathrm{p}<0.05)$ CHOL:TAG ratio but lower $(\mathrm{p}<0.05)$ TAG:CHOL ratio while rats in the MSG group had higher $(p<0.05)$ HDL:LDL ratio but lower $(p<0.05)$ LDL:HDL. The biochemical implications of this lipid profile component ratios are hitherto not fully known. We therefore speculated that higher CHOL:TAG or lower TAG:CHOL ratios could be indicative of beneficial lipid profile mix in the extract-treated rats whereas higher HDL:LDL or lower LDL:HDL ratios could be a pointer to deleterious lipid profile mix in the MSG-intoxicated rats. MSG-intoxication produced adverse influence on the lipid profile status of rats (Okediran et al., 2014; Mariyamma et al., 2009; Egbuonu et al., 2010d) while the result of this study suggested beneficial response on the lipid profile status of rats following exposure to the M. indica seed kernel. In support of the speculation, increaased LDL:HDL ratio predicted cardiovascular risk due to an increase in the atherogenic potential in the numerator but a decrease in the anti-atherosclerotic potential of the denominator 
(Millan et al., 2009).

\section{Conclusion}

In conclusion, the study demonstrated the preponderance of tannin in, and significant serum lipid lowering potential in normal and MSG-challenged rats of, the sample. Further studies aimed at using antinutrient-process-reduced sample in hyperlipidemia-related health-challenged models and collaborating the suggested implication of the studied lipid-profile-component-ratios are warranted and recommended.

\section{References}

Abdalla, E. M., Darwish, S. M., Ayad, E. H. E., \& El-Hamahmy, R.M. (2007). Egyptian mango by-product 1. Compositional quality of mango seed kernel. Food Chemistry, 103, 1134-1140. https://doi.org/10.1016/j.foodchem.2006.10.026

Ajila, C. M., \& Prasada-Rao, U. J. (2008). Protection against hydrogen peroxide induced oxidative damage in rat erythrocytes by Mangifera indica leaf peel extract. Food Chemical Toxicology, 46(1), 303-309. https://doi.org/10.1016/j.fct.2007.08.024

Albers, J. J., Warmick, G. R., \& Cheng, M. C. (1978). Determination of high density lipoprotein (HDL)-cholesterol. Lipids, 13, 925-932. https://doi.org/10.1007/BF02533852

Ali, M. R., Yong, M. J., Gyawali, R., Mosaddik, A., Ryu, Y. C., \& Cho, S. K. (2012). Mango (Mangifera indica L.) Peel extracts inhibit proliferation of HeLa Human Cervical Carcinoma Cell via induction of apoptosis. Journal of Korean Social Applied Biological Chemistry, 55, 397-405. https://doi.org/10.1007/s13765-012-1024-X

Amien, A. I., Fahmy, S. R., Abd-Elgleel, F. M., \& Elaskalany, S. M. (2015). Reno protective effect of Mangifera indica polysaccharides and silymarin against cyclophosphamide toxicity in rats. The Journal of Basic and Applied Zoology, 72, 154-162. https://doi.org/10.1016/j.jobaz.2015.09.006

Assmann, G., \& Gotto, A. M. (2004). HDL cholesterol and protective factors in artherosderosis. Circulation, 109, 8-14. https://doi.org/10.1161/01.CIR.0000131512.50667.46 Bhowmik, A., Khan, L. A., Akhter, M., \& Rokeya, B. (2009). Studies on the antidiabetic effects of Mangifera indica stem-barks and leaves on nondiabetic type-1 and type-2 diabetic model rats. Bangladesh Journal of Pharmacology, 4, 110-114. https://doi.org/10.3329/bjp.v4i2.2488

Carlson, L. A. (1963). Colorimetric determination of triglycerides in serum. Journal Athero. Res., 3, 334-339. https://doi.org/10.1016/S0368-1319(63)80012-5

Collison, K. S., Makhoul, N. J., Zaidi, M. Z., Al-Rabiah, R., Inglis, A., Andres, B. L., Ubungen, R., Shoukri, M., \& Al-Mohanna, F. A. (2012). Interactive effects of neonatal exposure to monosodium glutamate and aspartame on glucose homeostasis. Nutrition \& Metabolism, (Lond), 9(1), 58. https://doi.org/10.1186/1743-7075-9-58

Egbuonu, A. C. C. (2015a). Comparative investigation of the antibacterial and antifungal potentials of the extacts of watermelon (Citrullus lanatus) rind and seed. European Journal of Medicinal Plants, 9(4), 1-7. https://doi.org/10.9734/EJMP/2015/18142

Egbuonu, A. C. C. (2015b). Comparative investigation of the proximate and functional 
properties of watermelon (Citrullus lanatus) rind and seed. Research Journal of Environmental Toxicology, 9(3), 160-167. https://doi.org/10.3923/rjet.2015.160.167

Egbuonu, A. C. C. (2012). Sub-chronic concomitant ingestion of L-arginine and monosodium glutamate improves feed efficiency, lipid metabolism and antioxidant capacity in male Wistar rats. Pakistan Journal of Biological Sciences, 15(6), 301-305. https://doi.org/10.3923/pjbs.2012.301.305

Egbuonu, A. C. C., Ejikeme, P. M., \& Obasi, N. L. (2010b). Monosdium glutamate: Potentials at inducing prostate pathologies in male Wistar rats. African Journal of Biotechnology, 9(36), 5950-5954.

Egbuonu, A. C. C., Ejikeme, P. M., \&, Obasi N. L. (2010c). Influence of sub-chronic oral exposure to high monosodium glutamate on some serum markers of the renal functions in male Wistar rats. African Journal of Biochemistry Research, 4(9), 225-228.

Egbuonu, A. C. C., Ezeanyika, L. U. S., Ejikeme, P. M., \& Obidoa O. (2010a). Histomorphologic alterations in the liver of male Wistar rats treated with 1-arginine glutamate and monosodium glutamate. Research Journal of Environmental Toxicology, 4(4), 205-213. https://doi.org/10.3923/rjet.2010.205.213

Egbuonu, A. C. C., \& Ezeanyika, L. U. S. (2012). Effect of L-arginine on markers of metabolic syndrome related to abdominal obesity and disorder of lipid metabolism in female Wistar albino rats. American Journal of Biochemistry, 2(2), 7-13. https://doi.org/10.5923/j.ajb.20120202.02

Egbuonu, A. C. C., \& Nwankwo, N. E. (2012). Phytochemical properties of some solvent fractions of petroleum ether extract of the African mistletoe (Loranthus micranthus Linn) leaves and their antimicrobial activity. African Journal of Biotechnology, 11, 12595-12599.

Egbuonu, A. C. C., Obidoa, O., Ezeokonkwo, C. A., Ezaeanyika, L. U. S., \& Ejikeme, P. M. (2009b). Low dose oral administration of monosodium glutamate in male albino rats may be nephroprotective. Bio-Research, 7(1), 470-473. https://doi.org/10.4314/br.v7i1.45475

Egbuonu, A. C. C., Obidoa, O., Ezeokonkwo, C. A., Ejikeme, P. M., \& Ezeanyika, L. U. S. (2010d). Some biochemical effects of sub-acute oral administration of L-arginine on monosodium glutamate-fed Wistar albino rats 1: Body weight changes, serum cholesterol, creatinine, and sodium ion concentrations. Toxicol. and Environ. Chem, 92(7), 1331-1337. https://doi.org/10.1080/02772240903450645

Egbuonu, A .C. C., Obidoa, O., Ezeokonkwo, C. A., Ezaeanyika, L. U. S., \& Ejikeme, P. M. (2009a). Hepatotoxic effects of low dose oral administration of monosodium glutamate in male albino rats. African Journal of Biotechnology, 8(13), 3031-3035.

Egbuonu, A. C. C., \& Oriji, S. O. (2017). Pulverized Mangifera indica (mango) seed kernel mitigated monosodium glutamate-intoxicated rats' kidney histology and bio-functions. Journal of Nutritional Health and Food Science, 5(1), 1-7. https://doi.org/10.15226/jnhfs.2017.00193

Egbuonu, A. C. C., \& Osakwe, O. N. (2011). Effects of high monosodium glutamate on someserum markers of lipid status in male Wistar rats. Journal of Medicine\& Medical Science, 2(1), 653-656. 
Fowomola, M. A. (2010). Some nutrients and antinutrients content of mango (Mangifera indica) seed. African Journal of food Sciences, 4(8), 472-476.

Gemede, H. F., \& Negussie, R. (2014). Antinutritional Factors in Plant Foods: Potential Health Benefits and Adverse Effects. International Journal of Nutrition and Food Sciences, 3(4), 284-289. https://doi.org/10.11648/j.ijnfs.20140304.18

Husarova, V., \& Ostatnikova, D. (2013). Monosodium glutamate, toxic effects and their implications for human intake: A review. JMED Research, 1-12. https://doi.org/10.5171/2013.608765

Jaffe, A. S., Ravkilde, J., Roberts, R., Naslund, U., Apple, F. S., Galvani, M., \& Katus, H. (2000). It's time for a change to a troponin standard. Circulation, 102(11), 1216-1220. https://doi.org/10.1161/01.CIR.102.11.1216

Jagetia, G. C., \& Baliga, S. (2005). Radioprotection by mangiferin in DBAxC57BL mice: A $\begin{array}{llll}\text { preliminary } & \text { study. } & \text { Phytomedicine, } & \text { 209-215. }\end{array}$ https://doi.org/10.1016/j.phymed.2003.08.003

Li, X., Cui, X., Sun, X., Li, X., Zhu, Q., \& Li, W. (2010). Mangiferin prevents diabetic nephropathy progression in streptozotocin-induced diabetic rats. Phytotherapy Research, 24, 893-899.

Lucas, G. M., \& Markakas, P. (1975). Phytic acid and other phosphorus compounds of bean (Phaseolus vulgaris), J. Agric. Ed Chem., 23, 13-15. https://doi.org/10.1021/jf60197a016

Lucas, R. L., Lentz, K. D., \& Hale, A. S. Collection and preparation of blood products. Clinical Techniques in Small Animal Practice, 19(2), 55-62. https://doi.org/10.1053/j.ctsap.2004.01.007

Manal, S. T., \& Nawal, A. (2012). Adverse effects of monosodium glutamate on liver and kidney function in adult rats and potential protective effect of vitamins C and E. Food and Nutrition Sciences, 3(5), 651-659. https://doi.org/10.4236/fns.2012.35089

Mariyamma, T., Sujatha, K. S., \& Sisilamma, G. (2009). Protective effect of Piper longum Linn. on monosodium glutamate induced oxidative stress in rats. Indian Journal of Experimental Biology, 47, 186-192.

Mattson, M. P. (2008). "Glutamate and Neurotrophic Factors in Neuronal Plasticity and Disease," Annals of the New York Academy of Sciences, 1144, 97-112. https://doi.org/10.1196/annals.1418.005

Millan, J., Pinto, X., Munoz, A., Zunig, M., Rubies-Prat, J., Pallardo, L.F., Masana, L., Mangas, A., Hernandez-Mijares, A., Gonzalez-Santos, P., Ascaso, J., \& Pedro-Botet, J. (2009). Lipoprotein ratios: Physiological significance and clinical usefulness in cardiovascular prevention. Vasc Health Risk Manag., 5, 757-765.

Noratto, G. D., Bertoldi, M. C., Krenek, K., Talcott, S. T., Stringheta, P. C., \& Mertens-Talcott, S. U. (2010). Anticarcinogenic effects of polyphenolics from mango (Mangifera indica) varieties. Journal of Agricultural and Food Chemistry, 58(7), 4104-4112. https://doi.org/10.1021/jf903161g

Nzewi, D. C., \& Egbuonu, A. C. C. (2011a). Effect of boiling and roasting on some anti-nutrient factors of asparagus bean (Vigna sesquipedalis) flour. African Journal of Food 
Science and Technology, 2(3), 075-078.

Nzewi, D. \& Egbuonu, A.C.C. (2011b). Effect of boiling and roasting on the proximate properties of asparagus bean (Vigna sesquipedalis). African Journal of Biotechnology, 10(54), 11239-11244. https://doi.org/10.5897/AJB11.452

Okediran, B. S., Olurotimi, A. E., Rahman, S. A., Michael, O. G., \& Olukunle, J. O. (2014). Alteration in the lipid profile and liver enzymes of rats treated with monosodium glutamate. Sokoto Journal of Veterinary Sciences, 12(3), 42-46. https://doi.org/10.4314/sokjvs.v12i3.8

Prokopet, G., \& Unlenbruck, W. (2002). Protectine eine nenkalsse anti-kowperahlich verbindungen dish. Ges. Heit., 23, 318.

Rocha-Ribeiro, S. M., Queiroz, J. H., Lopes-Ribeiro de Queiroz, M. E., Campos, F. M., Pinheiro-Sant'ana, H. M. (2007). Antioxidant in mango (Mangifera indica L.) pulp. Plant Foods and Human Nutrition, 62(1), 13-17. https://doi.org/10.1007/s11130-006-0035-3

Schummer, C. M., Werner, U., Tennagels, N., Schmol, D., Haschke, G., Juretschke, H., Patel, M. S., Gerl, M., Kramer, W., \& Herling, A. W. (2008). Dysregulated pyruvate dehydrogenase complex in Zucker diabetic fatty rats. Am. J. Physiol. Endocrinol. Metab., 294, E88-E96. https://doi.org/10.1152/ajpendo.00178.2007

Shabani, Z., \& Sayadi, A. (2014). The Antimicrobial in Vitro Effects of Different Concentrations of Some Plant Extracts Including Tamarisk, March, Acetone and Mango. Journal of Applied Pharmaceutical Science, (5), 75-79.

Shah, K. A., Patel, M. B., Patel, R. J., \& Parmer, P. K. (2010). Mangifera indica (Mango). Pharmacognosy Review, 4(7), 42-48. https://doi.org/10.4103/0973-7847.65325

Shanthakumari, S., Mohan, V., \& Britto, J. (2008). Nutritional evaluation and elimination of toxic principles in wild yam (Dioscorea spp.). Tropical and Subtropical Agroecosystems, 8, 319-225.

Soetan, K., \& Oyewole, O. (2009). The need for adequate processing to reduce the antinutritional factors in plants used as human foods and animal feeds: A review. African Journal of Food Science, 3(9), 223-232.

Timsina, B., \& Kilingar, N. (2015). Mango seeds: A potential source for the isolation of bioactive compounds with anti-cancer activity. International Journal of Pharmacy and Pharmaceutical Science, 7(3), 89-95.

Vega-Vega, V., Silva-Espinoza, B. A., Cruz-Valenzuela, M. R., Bernal-Mercado, A. T., Gonzalez-Aguilar, G. A., \& Ruiz-Cruz, S. (2013). Antimicrobial and antioxidant properties of byproduct extracts of mango fruit. Journal of Applied Botany and Food Quality, 86, 205-211.

Veni, N. K., Karthika, D., Devi, M .S., Rubini, M. F., Vishalini, M., \& Pradeepa, Y. J. (2010). Analysis of monosodium l-glutamate in food products by high-performance thin layer chromatography. Journal of Young Pharmacology, 2, 297-300. https://doi.org/10.4103/0975-1483.66795

Yatnatti, S., Vijayalakshmi, D., Chandru, R. (2014). Processing and nutritive value of mango seed kernel flour. Current Research in Nutrition and Food Science, 2(3), 1-6. https://doi.org/10.12944/CRNFSJ.2.3.10

Zahedi, S. M., Asgarian, Z. S., Ersi, F. K., \& Seydi, A. (2016). Evaluating marketability of 
ten selected cultivars of mango. Open Journal of Ecology, 6, 219-224. https://doi.org/10.4236/oje.2016.65022

Zlatkis, A., Zak, B., \& Boyler, J. (1953). Colorimetric determination of cholesterol in serum. J. Lab. Clin. Med., 41, p.43c.

\section{Copyright Disclaimer}

Copyright reserved by the author(s).

This article is an open-access article distributed under the terms and conditions of the Creative Commons Attribution license (http://creativecommons.org/licenses/by/3.0/). 